\title{
Uji Aktivitas Ekstrak Daun Dan Akar Singawalang (Petiveria alliacea) Terhadap Penghambatan Tirosinase
}

\author{
Sholikha, $\mathrm{M}^{1}$, Nur M, $\mathrm{R}^{1}$ dan Mahfudza, A.R. ${ }^{1}$ \\ ${ }^{1}$ Program Studi Farmasi Fakultas Farmasi, Institut Sains dan Teknologi Nasional, Jalan Moh. Kahfi II, Srengseng Sawah, Jagakarsa, \\ Jakarta Selatan, DKI Jakarta, Indonesia, 12630
}

Reception date of the manuscript: 29 November 2020

Acceptance date of the manuscript: 4 Desember 2021

Publication date: 31 Desember 2021

\begin{abstract}
Tyrosinase is an enzyme that plays a role in the formation of skin pigments from a person because it is involved in the process of melanogenesis. Tyrosinase plays a very important role in the skin depigmentation process, there are several attempts to inhibit the skin depigmentation process, one of which is by inhibiting tyrosinase. Research on the leaves and roots of singawalang (Petiveria alliacea) was conducted to determine the potential as a tyrosinase inhibitor. Leaves and root extracts of singawalang were macerated with ethanol, then tested for identification of secondary metabolites. Singawalang leaves extract contains alkaloids, tannins and terpenoids while singawalang root extract contains alkaloids, flavonoids, tannins and terpenoids. Tyrosinase inhibitory activity used the microplate reader ELISA technique at a wavelength of $492 \mathrm{~nm}$. Tests were carried out on kojic acid as a comparison and L-DOPA as a substrate. The results of the tyrosinase inhibition activity test for the extracts of singawalang leaves, singawalang roots and kojic acid, $I C_{50} \mathrm{were} 9.817 \mathrm{mg} / \mathrm{mL}$, $4.987 \mathrm{mg} / \mathrm{mL}$ and $0.092 \mathrm{mg} / \mathrm{mL}$, respectively.
\end{abstract}

Keywords-Petiveria alliacea, Singawalang, Tyrosinase

\begin{abstract}
Abstrak- Tirosinase merupakan salah satu enzim yang berperan dalam pembentukan pigmen kulit dari seseorang karena terlibat dalam proses melanogenesis. Tirosinase sangat berperan terhadap proses depigmentasi kulit, terdapat beberapa upaya untuk menghambat proses depigmentasi kulit salah satunya dengan menghambat tirosinase. Penelitian pada daun dan akar singawalang (Petiveria alliacea) dilakukan untuk mengetahui adanya potensi sebagai inhibitor tirosinase. Ekstrak daun dan akar singawalang dimaserasi dengan etanol, kemudian dilakukan uji identifikasi metabolit sekunder. Ekstrak daun singawalang mengandung alkaloid, tanin dan terpenoid sedangkan ekstrak akar singawalang mengandung alkaloid, flavonoid, tanin dan terpenoid. Aktivitas penghambatan tirosinase menggunakan teknik microplate reader ELISA pada panjang gelombang $492 \mathrm{~nm}$. Pengujian dilakukan terhadap asam kojat sebagai pembanding dan L-DOPA sebagai substrat. Hasil uji aktivitas penghambatan tirosinase ekstrak daun singawalang, akar singawalang dan asam kojat, berturut-turut $I C_{50}$ sebesar $9,817 \mathrm{mg} / \mathrm{mL}, 4,987 \mathrm{mg} / \mathrm{mL}$ dan $0,092 \mathrm{mg} / \mathrm{mL}$.
\end{abstract}

Kata Kunci-Petiveria alliacea, Singawalang, Tirosinase

\section{Pendahuluan}

Singawalang (Petiveria alliacea) merupakan tanaman obat di Indonesia yang belum banyak dimanfaatkan oleh masyarakat Indonesia sendiri. Di berbagai negara seperti Karibia, Amerika Latin dan Afrika Barat telah menggunakan tanaman ini sebagai obat untuk meredakan nyeri, flu, peradangan, antitumor, antibakteri, antijamur, antiperlipidemia, antidiabetes dan untuk menangani penyakit lainnya (Mulyani, Y., Sukandar, E.Y., dan Adyana, 2012). Bagian tanaman yang umum digunakan adalah daun dan akar, akarnya mengandung senyawa yang berperan sebagai antioksidan (Rodrigues de Oliveira, 2016). Nilai $I C_{50}$ antioksidan singawalang sebesar $0,120 \mathrm{mg} / \mathrm{mL}$ dan kinerja antioksidan singawalang lebih

Penulis koresponden: Sholikha, M, E-mail: mona.farmasi@istn.ac.id baik dalam pelarut etanol bila dibandingkan dalam air (JideFaleye, F Ayomadewa, M.O., 2016).

Singawalang digunakan sebagai solusi untuk pengobatan alami karena mengandung metabolit sekunder seperti: saponin, alkaloid, flavonoid, fenol dan terpenoid (Ayodele et al., 2015). Proses oksidasi terjadi dalam biosintesis melanin yang memberikan pigmen pada kulit, hal tersebut normal terjadi karena merupakan bentuk reaksi kulit terhadap bahaya sinar ultraviole untuk melindungi tubuh. Namun, sinar matahari memicu munculnya masalah dermatologis dan terlihat pada lokasi yang sering terpapar sinar matahari khususnya bagian wajah yang sulit ditutupi. Masalah dermatologi yang umum terjadi adalah hiperpigmentasi, seperti, freckless (bercak hitam berukuran kecil), melasma (bercak hitam berbentuk tidak teratur), penuaan dini pada kulit hingga memicu kanker kulit (Pillaiyar et al., 2017).

Melanin dihasilkan oleh sel melanosit yang berada di la- 
pisan basal, secara fisiologis melain terdistribusi dari lapisan basal menuju lapisan korneum yang disebut melanogenesis. Proses tersebut melalui reangkaian reaksi oksidatif yang melibatkan asam amino tirosin dengan adanya enzim tirosinase (Mapunya et al., 2012). Melanin terdiri dari subunit pigmen yaitu eumelanin dan feomelanin, keduanya berasal dari asam amino tirosin. Pigmen yang memberikan warna gelap pada kulit adalah eumelanin (D'Orazio et al., 2013).

Enzim tirosinase adalah kunci dalam melanogenesis, sehingga dapat dijadikan sebagai sasaran untuk menghambat produksi melanin. Penghambat enzim tirosinase dapat diperoleh secara kimia dan alami, masing-masing memiliki kelemahan tertentu (Promden et al., 2018). Hidrokuinon memiliki potensi menyebabkan reaksi dermatitis serta iritasi, asam kojat bersifat karsinogenik dan vitamin $\mathrm{C}$ sensitif terhadap panas dan suhu. Saat ini penghambat tirosinase yang bersumber dari alam lebih menarik perhatian terutama dalam sediaan kosmetik karena mampu menghambat hiperpigmentasi pada kulit dengan konsep sehat dan aman (Chen et al., 2014).

Penghambat tirosinase yang bersumber dari alam dapat diperoleh dari metabolit sekunder tanaman, seperti flavonoid, furan, triterpen atau alkaloid (Chen et al., 2014). Flavonoid adalah salah satu turunan polifenol yang banyak terdistribusi pada bagian tanaman, seperti daun, biji, kulit, akar dan bunga tanaman. Terdapat 4000 flavonoid yang teridentifikasi dapat memberikan perlindungan terhadap radiasi sinar ultraviolet dengan peran terbesar sebagai penghambat tirosinase (Lee et al., 2016). Penelitian ini dilakukan untuk mengetahui aktivitas hambat dari ekstrak etanol daun dan akar singawalang terhadap tirosinase. Pengukuran aktivitas penghambatan tirosinase menggunakan teknik microplate reader ELISA secara in vitro diharapkan memberikan nilai $I C_{50}$ yang rendah sehingga dapat digunakan sebagai bahan alami alternatif untuk menghambat hiperpigmentasi dalam sediaan kosmetik.

\section{BAHAN DAN METODE}

\section{Bahan dan Alat}

Bahan yang digunakan adalah serbuk daun dan akar singawalang diperoleh dari Materia Medika Batu Malang, etanol, ammonia, Kloroform, pereaksi mayer, perekso dragendorf, $\mathrm{HCl}, \mathrm{NaNO} 2$ (Merck) 5\%, $\mathrm{AlCl} 3$ 10\%, NaOH (Merck) $1 \mathrm{~N}$, akuades, $\mathrm{FeCl} 3$ (Merck) $1 \%$, eter, asam asetat anhidrat, $\mathrm{H}_{2} \mathrm{SO}_{4}$ (Merck) pekat, dapar fosfat (Merck) $\mathrm{pH}$ 6,5, substrat L-DOPA (Sigma) $2 \mathrm{mM}$, enzim tirosinase (Sigma) $333 \mathrm{u} / \mathrm{mL}$ dan dimetil sulfoksida. Peralatan yang digunakan adalah Timbangan analitik digital, Rotary vaccum evaporator, Spektrofotometer UV-Vis, Multiplate well reader/ELISA (Epoch), Multiwell plates, Cawan penguap, Inkubator, Oven, Corong kaca, Batang pengaduk, Tabung reaksi, Kertas saring, Kain flanel, Alumunium foil, Erlenmeyer, Bunsen, Pipet tetes, Pipet mikro $(1000 \mu \mathrm{l})$, Penjepit kayu, Cawan penguap.

\section{Metode}

Serbuk daun dan akar singawalang masing-masing diekstrasi dengan metode maserasi dan diremaserasi, filtrat yang diperoleh dari hasil maserasi di evaporasi dan dikeringkan untuk memperoleh ekstrak kering. Ekstrak kering dilakukan uji penapisan fitokimia dan uji penghambatan enzim tirosinase. Uji penghambatan tirosinase dilakukan dengan intrumen
Tabel 1: Hasil Penapisan Fitokimia Ekstrak Metanol KULit BUAH KaWista)

\begin{tabular}{lll}
\hline Uji & Ekstrak Daun & Ekstrak Akar \\
\hline Alkaloid & + & + \\
Flavonoid & - & + \\
Tanin & + & + \\
Saponin & - & - \\
Triterpen & + & + \\
\hline
\end{tabular}

microplate reader ELISA dengan substrat L-DOPA pada panjang gelombang $492 \mathrm{~nm}$.

\section{Ekstraksi}

Serbuk daun dan akar singawalang masing-masing ditimbang sebanyak $250 \mathrm{~g}$ dan dimasukkan ke dalam wadah dengan kapasitas 4 L. Etanol ditambahkan ke dalam wadah sebanyak 2,5 L dan wadah ditutup dengan alumunium foil, dibiarkan selama $3 \times 24$ jam. Residu diekstraksi kembali dengan etanol selama $3 \times 24$ jam. Filtrat yang diperoleh disatukan kemudian dipekatkan dengan rotary evaporator pada suhu $40-50^{\circ} \mathrm{C}$ dan dikeringkan dengan freeze dryer.

\section{Penapisan Fitokimia}

Cara kerja Ekstrak akar singawalang di uji secara kualitatif untuk mengetahui senyawa yang terkandung, pengujian meliputi alkaloid, flavonoid, saponin, tanin, triterpen/steroid. Uji Alkaloid dilakukan dengan menimbang $1 \mathrm{mg}$ ekstrak dan dimasukkan ke dalam tabung reaksi, kemudian ditambahkan klorofom $2 \mathrm{~mL}$ dan amonia $2 \mathrm{~mL}$. Sampel dikocok dan disaring untuk memperoleh filtrate. Filtrat diteteskan pada keratas saring dan ditambahkan pereaksi Dragendorf dengan hasil dinyatakan positif bila terbentuk warna merah atau jingga. Selanjutnya, filtrat dimasukkan ke dalam tabung reaksi dan ditetesi 3-5 tetes larutan $\mathrm{H}_{2} \mathrm{SO}_{4}$ pekat lalu dikocok hingga terbentuk dua lapisan. Lapisan atas dipisahkan dan dibagi ke dalam dua tabung reaksi, kemudian filtrat ditetesi dengan pereaksi Mayer dan pereaksi Dragendorf dengan hasil dinyatakan positif bila masing-masing terbentuk endapan putih dan endapan merah jingga.

Uji Flavonoid dilakukan dengan menimbang ekstrak 0,5 mg dan ditambahkan $5 \mathrm{~mL}$ air panas, kemudian ditambahkan $1 \mathrm{~mL} \mathrm{NaNO} 25 \%, 1 \mathrm{~mL} \mathrm{AlCl} 310 \%$ dan $2 \mathrm{~mL} \mathrm{NaOH} 1 \mathrm{~N}$ lalu dikocok kuat dengan hasil dinyatakan positif bila terbentuk warna jingga hingga merah.

Uji Tanin dilakukan dengan menimbang ekstrak $0,5 \mathrm{mg}$ dan ditambahkan air $1 \mathrm{~mL}$, kemudian ditetesi dengan pereaksi $\mathrm{FeCl}_{3}$ sebanyak 10 tetes. Hasil dinyatakan positif bila terbentuk warna hijau kehitaman atau biru kehitaman.

Uji Saponin dilakukan dengan menimbang ekstrak 0,5 mg dan ditambahkan $3 \mathrm{~mL}$ air lalu dikocok sekitar 1 menit dan ditambahkan 2 tetes $\mathrm{HCl} 2 \mathrm{~N}$ dengan hasil positif bila terbentuk buih dengan tinggi yang stabil sekitar 7 menit.

Uji Triterpen/Steroid dilakukan dengan menimbang ekstrak $1 \mathrm{mg}$ dan direndam dengan eter selama 2 jam, lalu disaring dan diuapkan sehingga dihasilkan residu. Residu dimasukkan ke dalam tabung reaksi dan ditetesi dengan asam asetat anhidrat $2 \mathrm{~mL}$, kloroform $2 \mathrm{~mL}$ dan $\mathrm{H}_{2} \mathrm{SO}_{4}$ pekat ditambahkan perlahan melalui dinding tabung. Hasil positif dinyatakan dengan terbentuknya cincin merah untuk hasil triterpenoid dan cincin hijau untuk hasil steroid. 
Tabel 2: Hasil Pengujian Aktivitas Antibakteri)

\begin{tabular}{llll}
\hline Bahan Uji & Konsentrasi $(\mathrm{mg} / \mathrm{mL})$ & Inhibisi $(\%)$ & $I C_{50}(\mathrm{mg} / \mathrm{mL})$ \\
\hline & 2,5 & 22,928 & \\
Ekstrak Daun & 5 & 34,392 & \\
& 7,5 & 37,566 & 9,817 \\
& 10 & 54,427 & \\
& 12,5 & 55,379 & \\
& 2,5 & 33,968 & \\
Ekstrak Akar & 5 & 53,933 & \\
& 7,5 & 60,847 & 4,973 \\
& 10 & 62,716 & \\
& 12,5 & 63,845 & \\
& 0,0312 & 32,028 & \\
& 0,0625 & 36,049 & \\
Asam Kojat & 0,125 & 56,155 & 0,092 \\
& 0,25 & 64,480 & \\
& 0,5 & 82,575 & \\
\hline
\end{tabular}

\section{Uji Penghambatan Tirosinase}

Ekstrak daun dan akar masing-masing ditimbang sebanyak $50 \mathrm{mg}$ dan dilarutkan dalam labu ukur 10,0 $\mathrm{ml}$ dengan dimetil sulfoksida (DMSO) dan dicukupkan dengan larutan dapar fosfat $\mathrm{pH}$ 6,5 sampai tanda batas, sehingga diperoleh konsentrasi larutan $50 \mathrm{mg} / \mathrm{mL}$. Kemudian, larutan dibuat variasi konsentrasi 2,$5 ; 5 ; 7,5 ; 10 ; 12,5 \mathrm{mg} / \mathrm{mL}$ dalam larutan dapar fosfat $\mathrm{pH}$ 6,5. Asam kojat digunakan sebagai kontrol positif dengan variasi konsentrasi 0,$0151 ; 0,0312 ; 0,0625 ; 0,125$ $\mathrm{mg} / \mathrm{mL}$.

Larutan uji dipipet dan dimasukkan ke dalam sumur plat mikro, kemudian diinkubasi pada suhu $32^{\circ} \mathrm{C}$ selama 30 menit. Dopkarom terbentuk dengan adanya perubahan warna menjadi coklat dan reaksi penghambatan dapat terlihat dengan adanya penurunan intensitas warna yang pekat. Bahan uji diukur dengan microplate reader pada panjang gelombang $492 \mathrm{~nm}$. Nilai absobansi diubah dalam bentuk persen inhibisi dengan menggunakan perhitungan, sebagai berikut:

$$
\text { \% InhibisiTirosinase }=\frac{(A-B)^{\complement}(C-D)}{(A-B)} \times 100 \%
$$

keterangan: $\mathrm{A}=$ absorbansi larutan blangko $\mathrm{B}=$ absorbansi larutan blangko dan enzim $\mathrm{C}=$ absorbansi sampel $\mathrm{D}=$ absorbansi sampel dan enzim

\section{HASIL}

Serbuk daun dan akar singawalang diekstraksi dengan metode maserasi menggunakan pelarut etanol. Etanol merupakan pelarut universal yang dapat menarik sebagian besar senyawa polar. Hasil ekstrak daun diperoleh rendemen sebanyak $12,5 \%$ atau $20 \mathrm{~g}$ sedangkan ekstrak akar sebanyak 3,2\% atau $8 \mathrm{~g}$. Hasil penapisan fitokimia dilakukan untuk mengetahui senyawa yang terkandung pada ekstrak secara kualitatif. Hasil penapisan fitokimia tertera pada Tabel 1.

Pengukuran $I C_{50}$ dilakukan dengan menghubungan variasi konsentrasi terhadap persentase penghambatan. Nilai $I C_{50}$ adalah ukuran efektivitas ekstrak yang mampu menghambat $50 \%$ aktivitas enzim tirosinase. Hasil uji penghambatan tirosinase tertera pada tabel 2 .

\section{Pembahasan}

Pengujian aktivitas inhibitor tirosinase dilakukan dari hasil ekstrak daun dan akar singawalang (Petiveria alliacea) yang didapat untuk mengetahui daya inhibisi terbaik terhadap tirosinase dengan menggunakan asam kojat sebagai kontrol positifnya. Asam kojat merupakan salah satu agen anti tirosinase berasal dari jamur dengan kemampuan yang paling kuat sebagai penghambat tirosinase dan umum digunakan dalam sediaan kosmetik (Chang, 2009). Substrat yang digunakan adalah L-DOPA karena produk dopakrom dapat diukur dengan spektrofotometer pada panjang gelombang $492 \mathrm{~nm}$ bila dibandingkan dengan L-Tirosin akan menghasilkan dua produk yang dihasilkan, yaitu L-DOPA dan dopakrom dan L-DOPA tidak dapat diukur dengan spektrofotometer (Noor et al., 2018).

Untuk dapat mencegah pembentukan dopakuinon menjadi dopakrom salah satu caranya dengan menggunakan penghambat tirosinase. Pada ekstrak daun singawalang terdapat senyawa alami yang diduga berperan sebagai anti tirosinase, yaitu tanin. Tanin memiliki kemampuan sebagai anti tirosinase karena menghambat proses biosintesis melanin sehingga peningkatan produksi melanin tidak terjadi setelah paparan sinar UVB (Siahaan et al., 2017). Tanin terkondensasi atau proantosianidin merupakan oligomer atau polimer dari flavonoid yang mengandung unit flavan-3-ol. Karena tanin merupakan polimer dari flavonoid, diduga mempunyai mekanisme kerja yang hampir mirip dengan flavonoid, dimana flavonoid merupakan senyawa metabolit sekunder yang mempunyai kemampuan menangkap radikal bebas secara langsung. Aktivitas antioksidan dapat ditingkatkan melalui polimerisasi monomer flavonoid, misal proantosianidin sangat baik sebagai antioksidan karena tingginya jumlah gugus hidroksil dalam molekulnya (Arifin \& Ibrahim, 2018). Ikatan flavonoid dengan tembaga serta efek antioksidannya berperan dalam menghambat enzim tirosinase (Ohguchi et al., 2003).

Pada ekstrak akar singawalang terdapat senyawa alami yang diduga berperan sebagai anti tirosinase, yaitu flavonoid yang mampu berperan sebagai substrat dan menghambat pembentukan melanin. Dengan demikian yang akan berikatan dengan enzim tirosinase adalah posisi fenol dari flavonoid dengan atom $\mathrm{Cu}$ pada sisi aktif tirosinase, sehingga menyebabkan terhambatnya reaksi oksidasi sehingga pembentukan dopakuinon menjadi dopkarom berkurang (Lee et al., 2016). 
Hasil uji penghambatan tirosinase menunjukkan bahwa nilai $I C_{50}$ dari ekstrak akar singawalang lebih kecil dari daun sebesar 4,973 mg/mL. Hal tersebut dikarenakan kandungan metabolit sekunder dalam ekstrak akar lebih banyak dibandingkan dengan ekstrak daun yaitu adanya flavonoid. Asam kojat yang merupakan senyawa murni memiliki nilai $I C_{50}$ yang sangat kecil sebesar 0,092 mg/mL. Dari hasil penelitian ini, bisa ditindaklanjuti dengan proses fraksinasi ekstrak akar singawalang untuk mendapatkan senyawa flavonoid yang lebih spesifik sehingga diduga akan mendapatkan nilai $I C_{50}$ yang lebih kecil.

\section{KESIMPULAN}

Hasil uji aktivitas penghambatan tirosinase ekstrak daun singawalang, akar singawalang dan asam kojat, berturut-turut $I C_{50}$ sebesar $9,817 \mathrm{mg} / \mathrm{mL}, 4,987 \mathrm{mg} / \mathrm{mL}$ dan $0,092 \mathrm{mg} / \mathrm{mL}$.

\section{UCAPAN TERIMA KASIH}

Penulis mengucapkan terima kasih kepada pihak Laboratorium Fitokimia Fakultas Farmasi Institut Sains dan Teknologi Nasional (ISTN), pihak Lembaga Ilmu Pengetahuan Indonesia (LIPI) Laboratorium Biologi Cibinong dan pihak Laboratorium Biofarmaka Tropika IPB Bogor yang telah banyak membantu dalam penyelesaian penelitian ini sehingga dapat berjalan dengan baik.

\section{Daftar Pustaka}

Arifin, B., \& Ibrahim, S. (2018). Struktur, Bioaktivitas Dan Antioksidan Flavonoid. J. Zarah, 6(1), 21-29.

Ayodele, O. D., Oyegbade, O., \& Oseni, S. R. (2015). Phytochemical Analysis and Antioxidant Activities of Dry and Fresh Leaves of Petivera alliacea and Ocimum. Int. J. Sci. Basic Appl. Res., 24(3), 1-13.

Chang, T. S. (2009). An updated review of tyrosinase inhibitors. Int. J. Mol. Sci., 10(6), 2440-2475.

Chen, C.-Y., Lin, L.-C., Yang, W.-F., Bordon, J., \& D. Wang, H.-M. (2014). An Updated Organic Classification of Tyrosinase Inhibitors on Melanin Biosynthesis. Curr. Org. Chem., 19(1), 4-18.

D’Orazio, J., Jarrett, S., Amaro-Ortiz, A., \& Scott, T. (2013). UV radiation and the skin. Int. J. Mol. Sci., 14(6), 1222212248.

Lee, S. Y., Baek, N., \& Nam, T. G. (2016). Natural, semisynthetic and synthetic tyrosinase inhibitors. J. Enzyme Inhib. Med. Chem., 31(1), 1-13.

Mapunya, M. B., Nikolova, R. V., \& Lall, N. (2012). Melanogenesis and antityrosinase activity of selected South African plants. Evidence-based Complement. Altern. Med., 2012.

Mulyani, Y., Sukandar, E.Y., dan Adyana, I. (2012). AKTIVITAS ANTI BAKTERI SINGAWALANG (Petiveria alliaceae) TERHADAP BAKTERI YANG RESISTEN DAN PEKA TERHADAP ANTIBIOTIK. Bionatura, 14(1), 22-30

Noor, S. U., Faridah, \& Magdalena, P. (2018). Uji Aktivitas Inhibisi Enzim Tirosinase In-Vitro Krim Ekstrak Akar Manis (Glycyrrhiza glabra L.). J. Ilmu Kefarmasian Indones., 16(2), 150-158.
Ohguchi, K., Tanaka, T., Kido, T., Baba, K., Iinuma, M., Matsumoto, K., Akao, Y., \& Nozawa, Y. (2003). Effects of hydroxystilbene derivatives on tyrosinase activity. Biochem. Biophys. Res. Commun., 307(4), 861-863.

Pillaiyar, T., Manickam, M., \& Namasivayam, V. (2017). Skin whitening agents: Medicinal chemistry perspective of tyrosinase inhibitors. J. Enzyme Inhib. Med. Chem., 32(1), 403-425.

Promden, W., Viriyabancha, W., Monthakantirat, O., Umehara, K., Noguchi, H., \& De-Eknamkul, W. (2018). Correlation between the potency of flavonoids on mushroom tyrosinase inhibitory activity and melanin synthesis in melanocytes. Molecules, 23(6), 1-11.

Rodrigues de Oliveira, R. (2016). Phytochemical analysis and cytotoxic activity of Petiveria alliacea (Phytolaccaceae). Int. J. Sci., 2(04), 52-58.

Siahaan, E. R., Pangkahila, W., \& Wiraguna, A. A. G. P. (2017). Krim ekstrak kulit delima merah (Punica granatum) menghambat peningkatan jumlah melanin sama efektifnya dengan krim hidrokuinon pada kulit marmut (Cavia porcellus) betina yang dipapar sinar UVB. J. Biomedik, 9(1), 7-13. 